\title{
The Human Dream of Power. The Portrait of Science as a Conceptual Heritage of the Modern Era"
}

\author{
Aleksandra Derra \\ Nicolaus Copernicus University in Toruń, \\ Trinity College Dublin \\ aldewicz[]umk.pl derraa[]tcd.ie \\ Received January 2015; accepted May 2015; published Summer 2015.
}

\begin{abstract}
The article provides a compact review of the early modern science views of the nature of science, scientific method and knowledge, rationality and objectivity with respect to masculinity and femininity. Following primarily Galileo and Bacon's work, the author is interested in pointing out the most important ideas of the historically fixed ways of how people imagined the acquisition of knowledge, presented nature, understood the role of researchers, as well as what metaphors they applied in defining knowledge. Due to the vast and diverse material, the aim is not to sketch a complete and detailed portrait of the ideal of modern science, but to explore to what extent gender-related issues were of any significance here.
\end{abstract}

Keywords: rationality; objectivity; modern science; gender; gender problem in science.

HE THAT hath wife and children

hath given hostages to fortune; for they are impediments to great enterprises, either of virtue or mischief.

Certainly the best works, and of greatest merit for the public, have proceeded from the unmarried or childless men.

(Bacon 2009)

\footnotetext{
${ }^{11}$ This article significantly draws on my book Women in/of science. Gender problem in contemporary philosophy of science and research practice published in Polish (Warsaw 2013), particularly on chapter three. I am grateful to anonymous reviewers for their helpful content-related and linguistic remarks.
} 
In 1899, a French sculptor, Louis-Ernest Barrias, created a fascinating statue maintained in the art nouveau style typical of modernism, which became an object of an animated interest among interpreters of the concept of nature, historians of science, scholars and feminist researchers (Daston, Galison 2007). The sculpture, made from marble and onyx, is called La Nature se dévoilant à la Science (Nature Unveiling Herself to Science) and may today be admired at the Musee d'Orsay in Paris. It presents a beautiful, sensual woman clothed in a colourful tunic clasped under the breasts with a green malachite brooch representing a scarab. The woman holds a large veil over her slightly bowed head, without raising her eyes. The veil is tied at her hips and reveals her full and shapely bare breasts. The nakedness of her breasts and the arms raised above her head suggest that she intends to reveal much more: her shoulders, the bare back, the face, the hair, and, perhaps, after the veil is removed the tunic will fall off as well, especially since it gives the impression of being fastened very subtly.

The statue leaves no doubt that nature uncovers her secrets slowly, coyly, yet gracefully, holding an observer in an uncertainty filled with excitement and fascination, causing him to have his eyes riveted on it. Nature is beautiful, enticing, feminine, and perhaps a woman. On the one hand, the sculpture is an allegory of the relationship between science and nature in an artistic depiction, whereas on the other - it illustrates the convictions truly present in collective western thinking on the bonds between the scientist and the researched object. The said convictions were formed throughout history, they were being subject to particular changes, transformed along with modifications occurring in the understanding of science and nature, nonetheless they preserved the presence of numerous metaphors with which we used to describe the scientific studies of nature. Hence, one should not be surprised that the original version of the said sculpture was meant as an ornament of the façade of the main building of the faculty of medicine and pharmacy of Universite de Bordeaux. It is situated on the left from the stairs leading inside it, whereas to the right we will find a statue entitled Science by Pierre Jules Cavelie. In this version the woman is not wearing a tunic, her body is naked and nearly entirely revealed with the exception of the head and hair and her gesture with the shawl indicates that she is about to uncover all the secrets. All we need to do is commence studies and research. Thus, as we see, nature conceals great mysteries; however, proper conduct guarantees that she will reveal some of them. The question is what kind of conduct will be the most efficient? Which interpretation of it has been preserved in our thinking on practising science, starting with the ideals formulated in the modern era?

In this article I will be interested in reviewing historically fixed ways of how people imagined the acquisition of knowledge, presented nature, understood the role of researchers, as well as what metaphors they applied in defining knowledge and whether gender-related issues were of any significance there. 
I will not be able to provide a complete and detailed portrait of the ideal of modern science, I will be more interested in key concepts and their role in subsequent perception of practising science. One of the tasks of sensitised (and often oversensitive) feminist researchers about femininity and women consists in a scrupulous analysis of conceptual heritage used in the establishment of the foundations of the so-called modern science. What is particularly important is an analysis of ideals of objectivity, rationality, impartiality, which - as such researchers claim - were co-founded with convictions concerning nature, reason, masculinity or femininity and female roles that were prevalent at a particular time.

It is worth adding that I do not support formulation of a general thesis, such as: "modern natural philosophers urged that science should be masculine and conducted by men". Nonetheless, I believe it is worth illustrating the consequences concerned with the application of methodological postulates of the modern model of science in scientific practice as it seems that some of them are presently being realised in a caricatured and radicalised form. This involves in particular the relationship between the man (also the researcher) and nature, the evaluation of scientific discoveries, the blindness to noncognitive involvement of scientific practices as a non-problematic good that will bring about social benefits. Moreover, all of the above interrelations entangle beliefs concerning the man himself, including the relationships between the two sexes, which constitute the main object of my research.

I do realise that postulating a thesis stating that in the $17^{\text {th }}$ century, due to the activity of such thinkers as Francis Bacon, Galileo Galilei, and later, Robert Boyle or Isaac Newton, also referred to as the founding fathers of modern thinking on science, the western world witnessed a revolution in science is highly disputable for at least several reasons. There seems to be a general consent with regard to seeing Galileo as the creator of the foundations of the modern ideal of science. However, the matter becomes increasingly controversial with regard to Bacon's views, strongly rooted in the convictions of his predecessors and, thus, not entirely breaking away from the tradition. Moreover, it is also possible to find works in the history of science that point to the $13^{\text {th }}$ and $14^{\text {th }}$ centuries as critical for the establishment of the prototype of today's science. Already the term "revolution" requires further disambiguation, as it may not be accepted that the transformation in the way of conducting science was sudden and the thus far adopted way of thinking about knowledge had miraculously and unexpectedly vanished. It would also be difficult to defend the opinion according to which such a transformation could have occurred thanks to several difficult books, incomprehensible to the majority of people and published in a limited edition of copies. Both the changes in thinking about science and an alteration in practices viewed as scientific could have occurred gradually. This was partly due to the much broader modifications in the character of western societies, such as: the progressing sepa- 
ration between the faith and knowledge, the establishment of prototypic scientific institutions, the professionalisation of people involved in science, the utilisation of scientific discoveries in the production of useful devices. It is therefore highly certain that the $17^{\text {th }}$ century did not witness an abrupt establishment of homogeneous and standardised field concerned with acquiring knowledge with a defined methodology of conducting research. Thus, it is worth to follow Steven Shapin (Shapin 1996) in sensitising that science is a collective undertaking, hence its formation was affected by numerous diversified factors. The sole concept of "a scientist" or the word "science", as they are understood nowadays, began to be utilised in the second half of the $19^{\text {th }}$ century. It appears that the necessity to provide a different name for a researcher from "a philosopher" (natural) was raised by an English historian of science, William Whewell. In his discussion with Samuel Coleridge from the 1830s he maintained that just as an artist is a person that practises art, so should a person that practises science be referred to as a scientist. Interestingly, Whewell used this name to define a woman, the author of the book written in 1834 and reviewed by him, entitled On the Connection of the Physical Sciences - Mary Somerville ${ }^{12}$.

When I write about the concepts inherited from the thinkers of the past epoch in relation to science I do not forget about the fact that what contemporarily functions as science is significantly different from what was defined as knowledge in the $17^{\text {th }}, 18^{\text {th }}$ or even $19^{\text {th }}$ centuries, whereas the ideal of modern science may only partially be realised in methodological postulates of the science of today or its particular research (Bińczyk 2012).

I wish to highlight that it is impossible to point to a simple, homogeneous, causal links between the postulates voiced by Bacon, Galileo or Newton and the methods of conducting science or scientific practices of contemporary laboratories. Nonetheless, we may indicate a certain continuity in the tradition of utilising particular metaphors in thinking about science. What I am interested in are the traces of modern thinking about it that may be found in its contemporary understanding.

\section{Scientific thinking as the realm of rationality and objectivity}

When speaking of the inherited understanding of such categories as rationality or objectivity, the modern thinking of science is usually defined as a characteristic combination of Cartesian rationalism with modern empiricism of Bacon or Newton. Galileo believed that in order to practise science one needed "sense-experiences and necessary demonstrations" as well as "necessary proofs" (Galilei 1615). Bacon wrote that the hope for developing scientific in-

\footnotetext{
${ }^{12}$ See "Whewell-Coleridge debate" in Encyclopedia of Human Thermodynamics, Human Chemistry, and Human Physics, URL = <http://www.eoht.info/> and Noble 1992: 279.
} 
vestigations was achievable with "a closer and purer league between these two faculties, the experimental and the rational" (Bacon 1620: book 1, XCV) ${ }^{13}$. The imperfect human mind was no longer sufficient: "And the human understanding is like a false mirror, which, receiving rays irregularly, distorts and discolors the nature of things by mingling its own nature with it". (Bacon 1620: 1, XLI). There was a need of a discipline in the form of a method, using experimental approach and appropriate tools, a demand for "reason which is elicited from facts by a just and methodical process" (Bacon 1620: 1, XXVI). Newton emphasised that the properties of the body "are to be found through experiments" (Newton 1687, def. 1).

The rationality of scientific cognition had diversified definitions in the history of philosophy. What is significant from the perspective of my considerations is that the mathematical model of scientific cognition postulated by Galileo and Bacon was to guarantee certainty of results of cognition, and, at the same time, of cognitive progress. In Letter to Welser about the Solar Spot where Galileo cautiously indicated his new research that he was involved in, he warned that such a research should be announced only on condition that there is certainty, including that obtained from results of experiments (Galilei 2010). Whereas in Sidereus Nuncius he wrote that this may be ensured with proceeding in concord with reason: "But why should I use only plausible arguments when I can almost absolutely demonstrate my conclusion?" (Galilei 2004: 3). Bacon claimed what follows: "And inquiries into nature have the best result when they begin with physics and end in mathematics" (Bacon 1620: 2, VIII), at the same time pointing to the necessity to introduce a special language, free of ordinary concepts. He stressed that only reason could ensure proper usage of language that would not cloud the knowledge: "the ill and unfit choice of words wonderfully obstructs the understanding. Nor do the definitions or explanations wherewith in some things learned men are wont to guard and defend themselves, by any means set the matter right. But words plainly force and overrule the understanding, and throw all into confusion, and lead men away into numberless empty controversies and idle fancies" (Bacon 1620: 1, XLIII).

Additionally, reaching the said certainty was attainable because the researched object was clearly specified and particularised. Thus, it results that not everything could have or may constitute an object of a research as not everything can be defined as a rightful (real) element of nature. If, as it was postulated by Galilei in his Dialogue Concerning the Two Chief World Systems, Ptolemaic and Copernican, the scope of research on nature was designated with mathematical proofs, then from the very beginning of modern creation of knowledge the framework of the so-called nature ("external world") was

\footnotetext{
${ }^{13}$ Later I will refer to Bacon's work in a shorter version: year of publication, number of the bo ok, Roman numeral of the aphorism cited.
} 
defined in accordance with theoretical guidelines, whereas the discrepancies between the adopted model and the results of the postulated observations had to be omitted. One should remember that the experiments postulated by Bacon for a long time were not perceived as a credible source of cognition. Even as late as at the decline of the $17^{\text {th }}$ century the Parisian Academy of Sciences required that experiment results be adopted by majority of votes in the presence of at least over a dozen members of the Academy (Daston 1997: 49). The desirable mathematical methods of research permitted the achievement of excellence and certainty comparable with divine certainty. As Galileo put it: "(...) human intellect does understand some of [the propositions] perfectly and thus in these it has as much absolute certainty as Nature itself has. Of such are mathematical sciences alone, that is, geometry and arithmetic, in which the Divine intellect indeed knows infinitely more propositions since it knows all. But with regard to those few which human intellect does understand I believe that its knowledge equals the Divine in objective certainty for here it succeeds in understanding necessity beyond which there can be no greater sureness" (Galilei 1967: 103).

The postulate supporting implementation of a rational research approach is connected with the need to apply strictly defined procedures, both theoretical and practical. We may say, that it consists in a certain supervision of a cognitive situation. The combination of rationality with controllability is characteristic of western philosophical thinking not only with regard to the cognitive relation to the world but also to the cognising subject, which is obliged to prepare a detailed list of allowable research methods that Galileo, Bacon and Newton referred to. Moreover, the possibility to control an object of research ensures its intersubjective cognisability (as it is possible to present a given object, show, introduce, calculate) in concord with the concept of egalitarianism of science. Hence, rationality is strongly linked to intersubjectivity and a certain democracy of science, if I may use such a term. In the previously invoked work, Sidereus Nuncius, the messenger in the person of Galileo announced to all the discovery of new stars (Galilei 2004).

Being aware of the importance of conducting experiments, Galileo distinguishes between experientia, i.e. a colloquial, non-targeted, unmethodical passive experiment commonly based on observation, and experimentum, i.e. an experiment carried out purposefully, with the active participation of the subject, in a planned and well thought-out manner. He emphasises that an experiment is not random in nature. It is useful to apply tools serving as a certain extension of possibilities of the human mind which is not sufficient by itself. Instruments are a supplement to a well-defined experiment. When Galileo mentions tools, he stakes his hopes on the telescope he used to allow him to conclusively dispel the cognitive doubts regarding the researched objects: "In third place, I have observed the essence or substance of the Milky Way circle. By the aid of a telescope anyone may behold this in a manner which so dis- 
tinctly appeals to the senses that all the disputes which have tormented philosophers through so many ages are exploded at once by the unquestionable evidence of eyes, and we are freed from wordy disputes upon this subject" (Galilei 2004: 16b). Additionally Bacon emphasises the role that tools play in the consolidation of cognitive efforts: "(...) in every great work to be done by the hand of man it is manifestly impossible, without instruments and machinery, either for the strength of each to be exerted or the strength of all to be united" (Bacon 1620, preface). The term "instruments and machinery" is assigned a broad and exceptionally "modern" meaning. They encompass not only material objects but also inscription and all kinds of methods of recording of research results ${ }^{14}$. Both the recording and the utilisation of tools served in the interpretation of available data. Thus, the applied measures were carefully selected and, in a sense, "jointly created" the results, which seems to be obvious, for instance, to contemporary physics or biology.

What is particularly interesting is that scientific cognition should differ from other types of cognition by being concerned with the facts. Therefore, what are those facts from which Bacon instructs us to derive general theorems guaranteeing certainty of knowledge? The English "fact", Polish fakt, French fait or German Tatsache, Fakt originate from Latin word facere, i.e. "to do". In the $16^{\text {th }}$ century in England this word was used to refer to an activity or a deed. A fact refers to something that was done, something that actually (really) happened, to what we have experienced. In his writings, introduces a slight modification in the meaning of the discussed term. According to him, "fact" represents data guaranteed through experience on the basis of which it is possible to draw particular cognitive conclusions. Therefore, facts become relevant from epistemological point of view and their cognition is what constitutes the most vital aim of natural philosophy postulated by Bacon (Daston 1997: 45-46). Nevertheless, we have seen that obtaining the said data is not performed in a random manner. It is possible thanks to the use of specified methods, preparation of an experiment, utilisation of tools. As Stengers observes, to be precise, those facts are obtained following multiple cognitive procedures, well-defined and carefully selected (similarly to the objects that one may investigate). Hence, they are something that we are straightforwardly provided with. They are carefully prepared and, in a sense, produced through human cognitive interference. So, we have the grounds to rather call them artefacts, i.e. something that emerged as a result of undertaking numerous complex procedures (Stengers 2000: 51). Stengers likens the scientist involved in such a process of creation to a poet, since he produces artefacts thus creating, to a certain extent, fictitious worlds. And though the composite cognitive and institutional mechanisms the beings brought into existence within

\footnotetext{
${ }^{14}$ This curiously coincides with the views presented by Latour, who claimed that the method of data collection is what significantly distinguishes science from all other cognitive practices, see for example: Latour 1986.
} 
a given formula begin to become "real" (2000: 167). Such an interpretation would be compatible with the aforementioned origin of the word scientist in modern languages. The differentiation between facts and non-facts (subjective opinions, fiction, stories), on the other hand, was in her opinion also responsible for the establishment of a new type of politics that designated the boundaries between opinions and knowledge, as well as between those who are capable of distinguishing them by determining the distribution of power (Stengers 2000: 163). Was gender a significant criterion in this division?

\section{Institutions of modern science - the domain of men?}

In his texts Galileo rarely refers directly to women and their status in science. Surely he shared the convictions characteristic of his times with regard to intellectual limitations of women, their lack of access to "reasonable experiments and insightful observations" which were indispensable in the acquisition of reliable knowledge. In his essay Of Marriage And Single Life he sees the role of women in the following way: "Wives are young men's mistresses; companions for middle age; and old men's nurses" (Bacon 2009). Hence, it was unnecessary to state the obvious. Nevertheless in his Letter to Madame Christina of Lorraine, Grand Duchess of Tuscany, while discussing the superficial and erroneous interpretations of the Holy Bible he, not quite accidentally, quotes St. Jerome: "Hence we need not concern ourselves with the shallowness of those men whom grave and holy authors rightly reproach, and of whom in particular St. Jerome said, in reference to the Bible. This is ventured upon, lacerated, and taught by the garrulous old woman, the doting old man, and the prattling sophist before they have learned it. Others, led on by pride, weigh heavy words and philosophize amongst women concerning holy Scripture. Others-oh, shame!-learn from women what they teach to men, and (as if that were not enough) glibly expound to others that which they themselves do not understand" [bold typeface - A.D.] (Galilei 1615). In the cited fragment, women are depreciated, presented as those that provide only uncertain and superficial knowledge that they themselves fail to comprehend.

Galileo's biographers, to the contrary, provide quite a detailed report on his personal relations with women. The descriptions themselves and the emphasis applied in them paint a specific portrait of women who frequently disturb the researcher and make his life difficult (see the introductory citation). In the description of Galileo's parents, James Reston shows his admiration to the father who, despite the hard work and the noises of the house, is able to indulge in his passion for music, whereas he depicts the mother as a bitter, shrill and grouchy woman who never made peace with the misalliance of her marriage (Reston 1998: 6). When he talks about Galileo's great love and passion to the fourteen years younger Marina Gamba, presumably the mother of his three children, he adds that she had a reputation of a promiscuous woman. 
He neglects to make any remarks concerned with judgement of Galileo's attitude who never meant to marry Marina, lived separately and constantly complained on the financial burden regarding having children born out of wedlock (Reston 1998: 62). An unfavourable interpretation of his stance would allow noting that he abandoned the mother of his children, holding his scientific work over everything else, and later placed his daughters in a monastery in order to avoid the costs related to the possibility of their getting married (Noble 1992: 216).

In The New Atlantis and From the Great Restoration Bacon advocated a specific institutionalisation of scientific knowledge and propagated the idea of founding a scientific society, a special academy of sciences called "The House of Solomon". Its purpose was examining the secrets of God's creation, reserved exclusively to the chosen ones. We read from the very beginning: "'Lord God of heaven and earth; thou hast vouchsafed of thy grace, to those of our order to know thy works of creation, and true secrets of them; and to discern, as far as appertaineth to the generations of men, between divine miracles, works of nature, works of art and impostures, and illusions of all sorts" (Bacon 1626). The revival of science was the responsibility of fathers and sons that are capable of performing great deeds as long as their environment does not include women, which was explicitly emphasised in the citation recalled at the beginning. Bacon rarely speaks directly about women's subordination, he rather mentions it en passant and negligently while making comments related to them. As in his work The Advancement of Learning, when he refers to a fragment from the "Book of Proverbs" saying that a foolish son is a concern of the mother, as women are not good judges of virtue (Bacon 2006: 152). However, there are also his less-known texts that contain a more literal reasoning, what may be noted already in the title of his work which is Temporis Partis Masculus, sive Instauratio Magna Imperii Humani in Universum (The Masculine Birth of Time. The Great Instauration of the Dominion of Man Over the Universe, published probably in 1603 or 1608). When he writes about the plans to conquer nature he utilises metaphors connected with sexual, family or - more broadly - social relationships with the use of the metaphor of marriage between reason and nature (Dolby 1996: 267-283). In the legitimate marriage between reason and nature, the latter embodies the bride, whereas the role of a scientific mind is to cognitively tame it and make it subordinate. As was the case with the sculpture presented at the beginning, mysterious nature initially hides its laws and order; however, with her characteristic charm she will reveal them to a properly trained mind and will even allow herself to be used for his own purpose (Keller 1995: 37).

As we investigate the history of science, or more precisely - the preserved historical descriptions of natural philosophy, methods and tasks of knowledge construed in the modern era, we will observe straightforwardly expressed convictions regarding the closed character of scientific institutions reserved 
for men. For instance, Henry Oldenburg, the secretary of the Royal Society and editor of its journal Philosophical Transactions, made it clear that the objective of this modern scientific institution consisted in "(...) building hereafter a Masculine and useful Philosophy" (Oldenburg 1668). On the other hand, Joseph Glanvill, a member of the society, rebuked that there were no chances of reaching the truth with the use of female principles and values. The latter included passion, emotions, feelings, which result in excessive use of metaphorical language (Glanvill 1661: 135). Also a German historian of philosophy, Karl Joël, urged a return to masculine (männliche) philosophy by announcing the arrival of a masculine epoch, whereas George Zimmel argued that objectivity is in fact an attribute of masculinity (Schiebinger 1999: 67). In time, the ways of practising professed by the Society more and more boldly separated knowledge from values, thus formulating the rules of objectivity. Science was to become the realm of facts. It was incompatible with Bacon's recommendations, who believed that natural philosophy practised by people must respect the fact that the man is not only a reasonable creature but also a moral one (Bacon 2006). Thus, the reason itself is not sufficient to enable practising science.

One must realise that in the history of western culture, including its perception of science, there was a multitude of people who defended the view that women may also be wise, educated and deal with knowledge. Let me refer to the works of François Poullaine de Barre who published his texts in the $17^{\text {th }}$ century. This thinker, following the assumptions voiced by Descartes - quite too often burdened with responsibility for the depreciation of the body and carnality, i.e. something that was largely linked to femininity - drew a conclusion on the equality of sexes, which assigns him the pretensions to being called "the forgotten feminist" (Poullaine de Barre 1676). In his popular (five editions), and later entirely forgotten book with the meaningful title $D e$ l'egalite des deux sexes, discours physique et moral, ou l'on voit l'importance de se défaire des préjugez written in 1675, following the Cartesian method of initial rejection of prejudices, he reviews the popular beliefs (of philosophers, writers, theologians) on attributes which are characteristically masculine and feminine. By reference to intellectual potential and knowledge that I am particularly interested in, he propagates an exceptionally modern conviction stating that they depend on multifarious personal predispositions. In his opinion, initially such capabilities are the same for all: both the descent and the social class, thus the sex constitutes in this cases an insignificant variable, with knowledge (and later science) not being endowed with any particular gender. He believed that differences in the possessed knowledge or wisdom appear due to education being provided too late or in an improper manner. Interestingly, when professing the equality of feminine and masculine reason, he highlighted the significance of maternity and childcare by saying that the world could dispense with princes and soldiers and still continue to exist; 
however, it would not survive without those that take care of our children. Nevertheless this does not result in his elevation of the female sex over the male. In his defence of the thesis that women should be granted equal access to social life, including education, science, politics, de Barre fails to propose any solutions aimed at aiding the current situation. His works are philosophical texts, reflections supported with a concrete philosophical method, supplemented with personal observations that de Barre willingly sets forth, however without explicit political aspirations. This may be one of the reasons why his voice was entirely ignored. Nonetheless, it shows that only profound examination of numerous variables that resulted in women's exclusion from modern science, resulting in their absence in contemporary science, may indicate the real reasons for such a situation. The case of the discussed thinker manifests that theoretical grounds were also available to justify the opening of scientific institutions of western culture to women and, at the same time, develop the culture practising gender equality.

\section{The ideals of modern science in feminist terms}

In the feminist-oriented reflections on the historical heritage of WestEuropean approach to science there is an ongoing dispute whether typical scientific concepts, such as rationality, objectivity, impartiality and methodology of research or recommendation of carrying out experiments may be defined as masculine or reserved exclusively for men. How should we understand masculinity in such a context? How can we justify the conviction that rationality is masculine? Is objectivity interwoven into masculinity? (Derra 2010, Derra 2011). The dispute is moreover concerned with reflections whether the definitions of rationality and objectivity must be culturally sanctioned as contradictory to feminine attributes. One may ask what exactly caused science to become a male domain. I completely agree here with Evelyn Fox Keller when she says that it is impossible to truly comprehend the foundation and development of modern science if we fail to examine the language utilised in the specification of its intents. The said language made use of metaphors linked to gender, which manifested the values and aims that guided its development (Keller 1995: 43). Nevertheless, in feminist reflections on the establishment of modern science one may also encounter a thesis stating that science, including that of the modern era, has been and was male in principle. I am an opponent of formulating such general theses. I believe that a much more justifiable research, also from the point of view of reception of feminist theories, is one that demonstrates - following a proper formulation of criteria of masculinity and its understanding - the exact texts, phenomena, institutions or tools which may be deemed masculine. Additionally, as the author of the book entitled Le sexe du savoir, Michèle Le Doeuff, points out, even if the founding fathers of modern science, such as Bacon, utilised sexists ideas, their 
application commonly did not stem from their fundamental beliefs regarding science; nor did they use them to express their individual views on women and science, they were rather opinions typical of their times, formulated as a result of an interaction of various factors. Neither the philosophy of Bacon's epoch, not the cultural ideas regarding sex were bound to result in women's exclusion from scientific institutions postulated by him (Le Doeuff 2003: 155), which is illustrated, for instance, in the mentioned views of Poullain de Barre. As we know, Bacon himself criticised the negative heroes of feminist polemics, such as Plato, Aristotle, Aristotelian or the scholastic Fathers of the Church. Le Doeuff does not relieve Bacon from responsibility; however, she shows that presenting modern science using feminist epistemology as clearly "masculine" leads to an ahistorical examination of the origins of science. This validates the conviction that science is a matter of men, their values, goals and manner of acting, that its establishment was possible due to the intellectual achievements of men only, which caused gradual strengthening of erroneous opinions on the intellectual capabilities of women and their contribution in the history of human knowledge (Keller 1992: 19-20). One of important objectives of feminist research is to show that history abounded in extraordinary women involved in the extension of knowledge; however, they and their achievements had been forgotten. According to Le Doeuff, our intellectual development which also refers to feminists - is deprived of women-intellectuals or creators, of whom there was plenty, yet the following generations failed to preserve their accomplishments. This is even visible in the progenitor of feminist thought, Simone de Beauvoir, who surprisingly concludes The Second Sex with the words of a man, namely Arthur Rimbaud. Le Doeuff inquiries whether such an ending would take the same form if during English lessons de Beauvoir read the writings by Mary Wollstonecraft, studied the approaches of Gabrielle Suchon or Harriet Taylor in her philosophy classes, or familiarised herself with the history of women's voting rights in Anglo-Saxon world during history lectures (Le Doeuff 2003: 217).

Genevieve Lloyd demonstrates the complexity of the matter regarding feminist research on science (Lloyd 1993a, 1993b, 1996). First of all, she asks about the meaning of the adjective "masculine" in such expressions as "masculine reason", "masculine rationality". What are the effects of this particular reasoning in relation to science? Does it have anything to do with the properties of actual men and women? If so, does it concern the characteristics they are assigned to them, examined with defined methods, declared or some other? Do we understand reason as human capability, something that we disambiguate using common sense, or do we rather take into account its philosophical meaning? Or philosophical rationality? The latter, as we know, has evolved so which of its versions should we consider? Since Lloyd realises the existence of the aforementioned doubts, she focuses mainly on the symbolic presentations of what is masculine and feminine for particular philosophers. For in- 
stance, she notes that the Cartesian description of functioning of reason reveals prevalence of metaphors related to the sight and movement. She explicitly emphasises the active sides of the functioning of reason, hence she treats as more important those forms of activity that are connected with them (Lloyd 1993a: 79-81).

The aim that Descartes had in mind was to present the method of conducting research thanks to which all would be granted access to knowledge (therefore - even women). The distinction of reason as a power characteristic of man was not new, as it occurred in philosophy at its very beginnings, being particularly developed and highlighted by Aristotle (which did not stand in his way when he wrote about women's mental subordination). What was new, however, was that the procedure adequate in scientific investigation may be learnt with the use of principles of the method introduced by Descartes. As a result, it was possible to make a distinction between a methodical scientific research from research that was deprived of such a character (Lloyd 1993b: 39). Descartes thought of science in an egalitarian way, he claimed that it constituted a collective activity that could be developed only in cooperation with a great many. However, due to the fact that he introduced rigid boundaries between the reason and the body, res cogitans and res extensa, contemplation (abstraction) and typical activities of life, reasoning and emotions, thanks to which the actual creation of science could become a privilege only to the few. Descartes did not believe that only pure thinking was rational but the consequences of this division caused reason to be identified with it. To be general, we may say that Cartesian thinking on rationality envisages separation between what is carnal, emotional, feminine and what is rational, reasonable, masculine (Lloyd 1993a). Isn't the choice of properties, which we define as rational or objective, arbitrary in itself? Doesn't this show that Descartes himself, as a man, well off and of good education, a nobleman, and a spokesman of the epoch's outlooks, placed them above the others? Those properties may be interpreted as masculine, yet not universally masculine. In this matter, Lloyd allows for "a constructive difference of opinions" in feminist debate. I agree that explicit identification of the entire philosophical tradition, including philosophical approaches to science, with misogyny is not only an unreliable generalisation but it is also harmful to feminist thought as such. Thus, in the recalled debate we may argue in the same manner as it is done by Marcia Homiak, by noting that we may make attempts to interpret even the explicitly criticised in feminism Aristotelian model of rationality in such a way as to include in it emotions and desires (defined in culture as feminine). The said model guarantees room for friendship, taking care of others, but also for taking control over one's emotions, and may be good and useful both for men and women (Homiak 1993: 1-19). 
Presenting the discussed categories in a historical perspective allows us to realise that they are not of universal character nor are they timeless; moreover, their meaning was also subject to modification. One of the benefits that in my estimation results from feminist research on science rests in the manifestation of the entire spectrum of complex processes that contributed to both their modern and contemporary understanding. Historically speaking, the category of objectivity was not always related to specific scientific cognition and the scientific domain (Daston 1997: 38). This term was from the beginning of the $19^{\text {th }}$ century used to define a researcher or a perceived object and not the method applied in the research or perception. Objective cognition did not consist in levelling out the influence of the researching subject on the researched object, it did not entail an attempt to obtain a divine perspective "from nowhere", devoid of any impacts. In the $17^{\text {th }}$ century, where we traditionally position the birth of modern science, each representation depended on the observer's skills and situation, as well as tools and instruments that he was capable of using (Keller 1997: 315).

\section{War metaphors and cognition seen as conquering and reshaping}

Whether we like it or not, the history of western science is strictly related to the idea of waging a war and to wars occurring in reality. This is illustrated by the history of multiple domains and scientific institutions that owe their development to the growing technological demands of the military industry and warfare. Metaphors related to rule or conquest, on the other hand, are present in the description of a cognitive relation that we inherit from the modern era, or serve to grasp the specificity of relationships occurring between the elements of the world which are presented in particular scientific theories. From its modern beginnings, knowledge was depicted as "something to be obtained" through an arduous struggle resembling military actions. By reconstructing rationality as a particular way of utilising language constituting a defined organisation of science, Isabele Stengers points out that scientific studies and methodological recommendations of science are filled with concepts of "competition, polemic rivalry, complete dedication to an abstract goal" (Stengers 2000: 11).

A characteristic example of a connection between the development of scientific research and the needs of military development is provided by Schiebinger, who reminds us that a renowned and recognised scientificresearch institution, such as the Massachusetts Institute of Technology (MIT) flourished during World War Two. After the war it was twice as large as before its outbreak, with a quadrupled budget and ten times higher funds for research, $85 \%$ of which were financed by the Atomic Energy Commission. At the end of the war then President of MIT literally stated that its value for the country can be compare to the value of the army (Schiebinger 1999: 166-167). 
Many years later, espeically after the events of September 11 of 2001 an American act regarding the priority of internal security (Homeland Security Act), had a direct effect on the development of scientific research with welldefined objectives.

Numerous researchers, in the description of their own studies, utilize metaphors connected with warfare. For instance, when referring to the path towards the discovery of the structure of deoxyribonucleic acid, James D. Watson, in his work entitled The Double Helix makes use of such expressions as "struggle", "rivalry", "defeated", "the front" (Watson 1968). The language of multiple scientific disciplines, on the other hand, the metaphors it uses or the way it depicts the nature of the defined phenomena in their relation to the world, are construed upon the concept of an enemy-friend relationship and describe activities consisting in a fight. One of the most conspicuous illustrations is the poetics of immunology, in which the paradigm of differentiation between "an own-an alien" seems to be experiencing an ongoing crisis since the 1980s, with numerous interesting debates and alternative proposals having been made in relation to it (Cohen 2009). What is particularly significant is the metaphor usage in certain sections of biotechnology. One of the methods of conducting the manipulation of introducing foreign DNA into the cells of a random recipient, which was developed in the 1980s, is the so-called bioballistics (the cluster made from words 'biology' and 'ballistics') where so called gene guns are used. The idea that it is the best weapon which give an advantage in biological sense accompanies the $19^{\text {th }}$-century consideration of Darwin with regard to sexual selection and evolution of species when he emphasises that vitality and strength lead to an improvement of a race or species, whereas the right of males to fight over females is characteristic of the entire world of animals and savage (uncivilised) human tribes (Darwin 1871: ch. V).

When Bacon describes the goals of scientists or researchers he compares them with those who accompanied the chiefs conquering new areas in order to be successful, to complete conquests, make gains. Already as a twenty-year-old man he announced in his texts the fulfilment of a great revival as one of the most important achievements of his times, the revival consisting in the restoration of human rule over the world (Bacon 1626). These concepts, in a slightly altered form, were confirmed by Galileo, who refers to the Biblical record on the man's rule over the nature, believing that knowledge will enable us to recover the power that we had lost as a result of a sinful fall (Webster 1982). In the above understanding, knowledge not only originated from the God's bestowal, which would justify its acquisition with all available resources (vide the freedom of scientific research), but the possession of it was to guide the man towards his mightiness, endow him with unimaginable possibilities, including the power. Bacon was deeply convinced that both through faith and religion, as well as through the practice of science, the man that fell from his state of innocence will be able to rebuild his dominion over creation (Bacon 
1620, 2, LII). In this perspective, science requires certain effort but constitutes an enterprise that is worth taking. Being two centuries ahead of the classical understanding of the relationship between knowledge and power defined by Michel Foucault, Bacon writes that: "Human knowledge and human power meet in one" (Bacon 1620: 1, III). Nonetheless, the man's or researcher's relation to the nature is described by him in an equivocal manner. Man, being the servant and interpreter of Nature (Bacon 1620: 1, I), which may be interpreted as an expression of a great respect towards nature and its secrets. On the other hand, however, the man is to "overcome nature in action" which puts it in a position of a potential enemy. From this standpoint, the aim of science is to gain a greater power over nature, although it is necessary to add that it is expected to occur without using violence, by merely listening to nature. Bacon writes that if nature is to be commanded, it must be obeyed (Bacon 1620: 1, III). He criticises the misleading philosophy of Plato, Aristotle or Galen for, among other things, depreciating human power. Nevertheless he realises that this power is limited (Bacon 1815: 4) and knowledge, among other things, serves recognition of those limitations. Therefore, he distinguished among three different situations connected with nature and recommended that the manner of proceeding be adjusted to them. Namely, nature may be free, in which case it works accordingly to its laws, without any distortions; it may be influenced by particular factors disturbing the natural course (for example monsters); and finally, it may be beset and tamed with resources available to humans (Bacon 1815: 3). In the latter case we are faced with art as one of the components of natural history, since nature becomes limited with human acts of creation. Bacon assumes that natural things differ from artificial ones through what may be done with them and how effective or efficient they are. We may manage nature but also change it and transform it only when we know it and realise in which situations this is achievable (Bacon 1620, 2, VI). The particularly interesting metaphors used in his descriptions are those referring to any kind of activity which can reshape the world. In the book The New Atlantis and From the Great Restoration he is interested in the situations when human activity can change the natural conduct of Nature by putting pressure on it and by forming it in a desired way. Similarly, Boyle notes two different approaches in natural philosophy research. He distinguishes between researchers who m e r ely aim to become familiarised with nature and those, presumably preferred, who in addition to this wish to "order it", cause it to be at their service (Boyle 1744). A bit later, i.e. in the $18^{\text {th }}$ century, similar voices were raised; however, the usage of metaphors became even more pointed and literal. For instance, William Derham writes that if it is necessary, humanity will be able to ransack the entire globe, penetrate the earth and reach the most distance regions of the world. The demand for such actions is justified by him with the fact of acquiring knowledge but also achieving prosperity or, simply, satisfying human whims (Derham 1754, b. II: 37). 
Modern co-founders of the fundamentals of science in turn encourage one another to overcome nature and to serve it; however, eventually, similarly to Bacon, they do not conceal the fact that the purpose of science is to "(...) make nature serve the business and conveniences of man" (Bacon 1620, 2, XXXI). Numerous interpreters show that what is in fact meant is wielding power and control over nature. Carolyn Merchant, for example, straightforwardly accuses Bacon that he sanctions exploitation of nature with the support of cognitive values, which results in adopting a view in science that the above mentioned research procedure is justified (Merchant 1980: 164) ${ }^{15}$. Thus, we begin to understand the conquest of nature as a progress, substantiate the use of its resources with satisfying human needs. It does not come as a surprise then that the expansion European thinking about the world, imposing on the countries conquered by Europe the scientific description of the world was justified by implying that it serves civilizational development.

\section{Progress as the benefit of the condition of man which is to be achieved through science}

The concept of progress present in philosophical (and not only) postulates related to the enlightenment of humanity and modernisation of the world has accompanied science since the modern times. It is not incidental that Bacon justifies the idea of conquering nature, expressed with the use of metaphors related to warfare, with acting for the improvement of human fate, which he explicitly states in the introduction to Novum Organum. As we have seen he believed that due to the cognitive containment of nature realised with the new science, humanity will once more be able to dominate the world, which has been the case before the commitment of the original sin. He criticises the thus far practised and postulated natural philosophy, not only due to its application of speculative methods but also because, in his assessment "(...) from all these systems of the Greeks, and their ramifications through particular sciences, there can hardly after the lapse of so many years be adduced a single experiment which tends to relieve and benefit the condition of man, and which can with truth be referred to the speculations and theories of philosophy" (Bacon 1620, 1, LXXIII). He argued that the aim of the new science postulated by him should consist in building of the foundations enabling amassment of human well-being and increasing the power of humanity. He wrote: „We must begin anew from the very foundations, unless we would revolve forever in a circle with mean and contemptible progress" (Bacon 1620, 1, XXXI). What is also characteristic of our times, philosophy and intellectual sciences, as he called them, was the lack of progress, stagnation and plunging in self-indulgence regarding one's achievements. In his opinion, idleness was

\footnotetext{
${ }^{15}$ See Vickers 2008 for the critique of Merchant feminist interpretation of Bacon's metaphors.
} 
moreover characteristic of the old science, as opposed to mechanical sciences, which he saw as "continually thriving and growing, as having in them a breath of life" (Bacon 1620, 1, LXXIV).

According to Bacon, the most vital goal of science is the cognitive one, i.e. the discovery of significant properties of nature. The implementation of this goal allowed formulation of laws that rule the nature, which, on the other hand, enabled having control over it. At the same time, it opened the prospect of reaching the subordinate, yet equally important goal consisting in the transformation of nature or - to be more precise: the transformation of concrete bodies" (Bacon 1620, 2, I). We may say with a certain exaggeration that relieving human misery is achievable through science, as it produces useful tools, objects, mechanisms and measures. Thus, the usefulness of the results of science has from its very beginnings been an important drive of its development and the criterion in the evaluation of its usability. The catalogue of what we wish to achieve through the sciences, according to Bacon, could easily be presented today as well, and the validity of enlisted goals could find contemporary justification. He enumerates "the prolongation of life, the retardation of age, the alleviation of pain, the repairing of natural defects, the deceiving of the senses; arts of binding and inciting the affections, of illuminating and exalting the intellectual faculties, of transmuting substances, of strengthening and multiplying motions at will, of making impressions and alterations in the air, of bringing down and procuring celestial influences; arts of divining things future, and bringing things distant near, and revealing things secret; and many more" (Bacon 1620, 2, LXXXVII).

What is curious is that the concepts related to the prolongation of human life and health improvement, so crucial to the present-day development of medical sciences, pharmacology and biotechnology, as well as with regard to the role of research conducted within it for modern science, appeared in western culture so visibly already in the $17^{\text {th }}$ century. Somewhat later, Darwin himself described the intellectual and moral development of the man in his famous work The Descent of Man. He was convinced that one of the regular principles of human societies lies in the progress, which, in his view, was strongly linked to the development of various biological capabilities (he refers to this as an organic progress), thus giving rise to higher intellectual and social skills (Darwin 1871, ch. XXI). The idea to connect biological development and the development of historically evolving societies and refer to it as progress has been present in philosophical thinking for a long time. It is visible in Jean Baptist Lamarck, or later in Herbert Spencer. Therefore, Darwin expressed the popular conviction of his times that human development consisted in slowly being risen to higher levels of civilisation, which, roughly speaking, allow constant 
improvement in the adjustment to the changeable living conditions and extension of survival time ${ }^{16}$.

It seems that in the contemporary scientific research what is progressive is commonly treated by definition as innovative (new, better, more modern, whatever that means), possible to use (in various branches of industry), with the list of applications that will be used and sold to the benefit of an economic development of a society. A malicious critic would say that in the name of human development scientists are to contribute to the production of anything that may be consumed or calculated into money as welfare in literal sense that is convertible and computable. The mightiness of humanity, although already described by Bacon, which was to be manifested through its conquest of nature, seems to be expressed today in a quite caricatured form. It seems that knowledge as such is not perceived nowadays as an autotelic value, nor do we develop it only with regard to cognitive values. Hence, science serves the amassment of goods and a specifically understood civilizational development. It does not come as a surprise then that scientific research is more often justified with the necessity to improve the well-being of societies, which involves, as it is professed, cooperation between the science and the world of industry and business (Krimsky 2004).

Let me go back to the beautiful woman from Louis-Ernest Barrias' fascinating statue Nature Unveiling Herself to Science, with which I have started this article. Let us play with its possible meanings for a while. I already said that it gracefully reveals her secrets in front of the excited observer - a scientist who is equipped with proper tools and means. She is already treated as an object, though still a bit unknown, mysterious, surprising and not to be fully possessed, at least not easily. Yet her veil is fastened very subtly and it is tempting to be able to get it off completely and have access to all secrets of Nature. We are getting close to the point where fascination - previously imperceptibly entangled with a kind of respect - has changed into desire to know more and more. This desire to possess knowledge comes together with developing all possible helpful tools, making use of them in order to transform the Nature (world, the outside) exclusively for the observer's own sake. To treat something as an object is always a first step towards the possibility of using it, "consuming" it, so to speak. It is not an inevitable step, but quite likely to be taken, as we can see from analysing both symbolic representations of the contemporary science and some of its practices.

\footnotetext{
${ }^{16}$ The ideas of progress and development were explored by such philosophers as, for instance, Leibniz, Rousseau, Hegel or Comte; cf. Baum 1988: 14-15.
} 


\section{Literature}

Bacon, F. 1620. The New Organon Or True Directions Concerning the Interpretation of Nature. URL = <http://www.constitution .org/bacon/nov_org.htm>, 15.11.2014.

Bacon, F. 1626. The New Atlantis. The Internet Wiretap edition. From Ideal Commonwealths.P.F. Collier \& Son, New York. URL $=<$ http://oregon state.edu/instruct/phl302/texts/bacon/atlantis.html>, 15.11.2014.

Bacon, F. 1815. The Works of Francis Bacon. De Augmentis Scientiarum. London, URL = <http://books.google.pl/books/about/The_Works_of_Francis _Bacon_De_augmentis.html?id=f3ENAAAAYAAJ\&redir_esc=y>, 05.12.2012.

Bacon, F. 2006. The Advancement of Learning. Gloucestershire: Dodo Press.

Bacon, F. 2009. The Essays Or Counsels, Civil And Moral. URL = <http://www.gu tenberg.org/files/575/575-h/575-h.htm\#link2H_4_0007>, 15.11.2014.

Baum, R.F. 1988. Doctors of Modernity: Darwin, Marx and Freud. Illinois: Sherwood Sugden \& Company Publishers.

Bińczyk, E. 2012. Technonauka w społeczeństwie ryzyka. Filozofia wobec niepożądanych następstw praktycznego sukcesu nauki. Toruń: Wydawnictwo Naukowe Uniwersytetu Mikołaja Kopernika.

Boyle, R. 1744. The Works of Robert Boyle. London: A Millar.

Cohen, E. 2009. A Body Worth Defending, Immunity, Biopolitics, and the Apotheosis of the Modern Body. Durham: Duke University Press.

Darwin, Ch. 1871. The Descent of Man, and Selection in Relation to Sex. vol. II, URL = <http://www.gutenberg.org/files/36520/36520-h/36520-h.htm>, 15.11.2014.

Daston, L. 1997. Baconian Facts, Academic Civility and the Prehistory of Objectivity. A. Megill, ed. Rethinking Objectivity: 37-63. Durham, London: Duke University Press.

Daston, L., Galison P. 2007. Objectivity. New York: Zone Books.

Derham, W. 1754. Physico-Theology. London: Innys and Richardson.

Derra, A. 2010. Czy racjonalność może być męska? O języku nauki z perspektywy feministycznej. Annales Universitatis Mariae Curie-Skłodowska, t. XXXV, nr 2: 169-195.

Derra, A. 2011. Obiektywność spleciona z męskością. O języku nauki z perspektywy feministycznej. Teksty Drugie, nr 4: 49-69.

Dolby, R. G. A. 1996. Uncertain Knowledge. An Image of Science for a Changing World. Cambridge: Cambridge University Press. 
Galilei, G. 1615. Letter to Madame Christina of Lorraine, Grand Duchess of Tuscany. URL = <http://inters.org/galilei-madame-christina-Lorraine $>$, 15.11.2014.

Galilei, G. 1967 (1632). Dialogue Concerning the Two Chief World Systems. Berkley: University of California Press.

Galilei, G. 2004. Siderus Nuncius, homepages.wmich.edu/ mcgrew/Siderius.pdf [15.11.2014]

Galilei, G. 2010. Second Letter from Galileo to Welser about the Solar Spot. G. Galilei, Scheiner Ch., red. On Sunspots, Chicago: The University of Chicago Press.

Glanvill, J. 1661. The Vanity of Dogmatizing. Reprinted in: Fascimile Text Society (1931). New York: Columbia University Press.

Homiak, M. 1993. Feminism and Aristotle's rational ideal. L. Antony, Ch. Witt, eds. A Mind of One's Own. Feminist Essays on Reason and Objectivity: 1-19. Boulder-San Francisco-Oxford: Westview Press.

Keller Fox, E. 1995. Reflections on Gender and Science. New Haven- London: Yale University Press.

Keller Fox, E. 1992. Secrets of Life. Secrets of Death. Essays on Language, Gender and Science. London-New York: Routledge.

Keller Fox, E. 1997. The Paradox of Scientific Subjectivity. A. Megill, ed. Rethinking Objectivity: 313-333. Durham-London: Duke University Press.

Krimsky S. 2004. Science in the Private Interest. Has the Lure of Profits Corrupted Biomedical Research. Oxford: Rowman \& Littlefield Publishers.

Latour, B. 1986. Visualisation and Cognition: Drawing Things Together. H. Kuklick, ed. Knowledge and Society Studies in the Sociology of Culture Past and Present: 1-40, Jai Press, vol. 6.

Le Doeuff, M. 2003. The Sex of Knowing. New York-London: Routledge.

Lloyd, G. 1993a. Maleness, Metaphor, and the 'Crisis' of Reason. L. Antony, Ch.Witt, eds. A Mind of One's Own. Feminist Essays on Reason and Objectivity: 69-83. Boulder-San Francisco-Oxford: Westview Press,.

Lloyd, G. 1993b. The Man of Reason. 'Male' \& 'Female' in Western Philosophy. London: Routledge.

Lloyd, G. 1996. Reason, Science and the Domination of Matter. H. Longino, E. Fox Keller, eds. Feminism and Science: 41-57. Oxford: Oxford University Press.

Merchant, C. 1980. The Death of Nature. Women, Ecology and the Scientific Revolution. Cambridge-London: Harper\&Row Publishers. 
Newton, I. 1687. The Mathematical Principles of Natural Philosophy. URL = $<$ http://www.google.ie/url?sa=t\&rct=j\&q=\&esrc=s\&source=web\&cd=2\&ved =0CCUQFjAB\&url=http\%3A\%2F\%2Fwww.17centurymaths.com\%2Fconten ts\%2Fnewton\%2Fdefs\%2520axioms.pdf\&ei=Gh5nVNueM4Hfao6_gZAK\&u sg=AFQjCNHL8Qhj0M-ZpZh9xLzjSqAws3RICw>, 24.02.2015.

Noble, D. 1992. A World Without Women. The Christian Clerical Culture of Western Science. Oxford: Oxford University Press.

Oldenburg, H. 1668. Letter to Lord Arlington. Philosophical Transactions, vol. 3.

Poullaine de Barre, F. 1676. De l'Égalité des deux sexes, discours physique et moral où l'on voit l'importance de se défaire des préjugez. Paris, J. Du Puis, $\mathrm{URL}=<$ http://gallica.bnf.fr/ark:/12148/bpt6k82363t>, 2.02.2015.

Reston, J. 1994. Galileo: a Life. New York: HarperCollins Publishers

Schiebinger, L. 1999. Has Feminism Changed Science? Cambridge: Harvard University Press.

Shapin, S. 1996. The Scientific Revolution. Chicago, London: Chicago University Press.

Stengers, I. 2000. The Invention of Modern Science. Minneapolis-London: University of Minnesota Press.

Vickers, B. 2008. Francis Bacon, Feminist Historiography, and the Dominion of Nature. Journal of the History of Ideas, vol. 69, no 1: 117-141.

Watson, J. 1968. The Double Helix: A Personal Account of the Discovery of the Structure of DNA. New York: Atheneum.

Webster, Ch. 1982. From Paracelsus to Newton. Magic and the Making of Modern Science. Cambridge: Cambridge University Press. 